\title{
Role of individual susceptibility in risk assessment of pesticides
}

\author{
G Leng, J Lewalter
}

\begin{abstract}
Objectives-This study presents criteria for assessing the individual pesticide burden of workers in the chemical industry. Methods-A group of 1003 workers exposed to methylparathion or ethylparathion (alkyl phosphates), propoxur (carbamate), or cyfluthrin (pyrethroid) was investigated. After exposure to methylparathion or ethylparathion the methylparathion or ethylparathion and methylparaoxon or ethylparaoxon concentrations in plasma, the p-nitrophenol concentration in urine, and the activities of cholinesterase and acetylcholinesterase were measured. For exposure to propoxur the propoxur concentration in plasma, the 2-isopropoxyphenol concentration in urine, and the cholinesterase and acetylcholinesterase activities were measured. For exposure to cyfluthrin the cyfluthrin concentration in plasma was measured.
\end{abstract}

Results-At the same propoxur concentration only workers with a low individual acetylcholinesterase activity reported symptoms. Workers who metabolised cyfluthrin rapidly reported less symptoms than workers with a lower rate of metabolism. This tendency was also evident in cases of mixed exposure (cyfluthrin and methylparathion).

Conclusions-In the assessment of exposure to pesticides susceptibility of the individual person has to be considered.

(Occup Environ Med 1999;56:449-453)

Keywords: risk assessment; pesticides; individual susceptibility

Alkyl phosphates, carbamates, and pyrethroids are among the pesticides most often used. People handling pesticides do not only include workers in the chemical industry (production, filling, formulation), farmers, and pest control operators but also the consumers. The applicator should bear in mind that an improper use of pesticides may lead to adverse health effects. ${ }^{12}$ For objective assessment of exposure to pesticides it is recommended that the pesticides and specific enzymes in blood and the corresponding metabolites in urine are measured by standard biological monitoring. ${ }^{3-7}$ The measurement of the pesticide in blood is important, because in many cases the unchanged pesticide is responsible for adverse health effects. The renally eliminated metabolites often represent the detoxified part of the pesticide. The amount of metabolites in urine gives information about the magnitude of
Table 1 Overview of applied methods

\begin{tabular}{llll}
\hline Substance & Matrix & Method & $\begin{array}{c}\text { Detection } \\
\text { limit }^{\text {ref }}(\mu \mathrm{g} / \mathrm{l})\end{array}$ \\
\hline $\begin{array}{l}\text { Ethylparathion } \\
\text { Ethylparaoxon }\end{array}$ & Plasma & GC/MS & $5.0^{21}$ \\
$\begin{array}{l}\text { Methylparathion } \\
\text { Methylparaoxon }\end{array}$ & Plasma & GC/MS & $10^{21}$ \\
p-Nitrophenol & Plasma & GC/MS & $5.0^{21}$ \\
Propoxur & Urine & GC/MS & $10^{21}$ \\
2-Isopropoxyphenol & Plasma & GC/MS & $10^{23}$ \\
Cyfluthrin & Urine & HPLC & $10^{24}$ \\
& Plasma & GC/MS & $0.5^{25} 26$
\end{tabular}

$\overline{\mathrm{GC} / \mathrm{MS}=\text { gas chromatrography/mass spectroscopy; HPLC=high }}$ performance liquid chromatography.

exposure and in some cases about the metabolic capacity of the subjects. ${ }^{6-11}$ Several studies have shown that comparable pesticide concentrations may lead to totally different biological effects. ${ }^{9}{ }^{12-14}$ For assessing individual susceptibilities, the key enzymes essential for pesticide metabolism should be measured. Alkyl phosphates, carbamates, and pyrethroids are metabolised by esterases. An inhibition of the acetylcholinesterase activity indicates an exposure to alkyl phosphates or carbamates. ${ }^{15}$ On the other hand, this enzyme is not a marker of exposure to pyrethroid. Here, no suitable marker of effect is known yet. ${ }^{16}$

It is known that up to $30 \%$ of the population has low cholinesterase and paraoxonase activities. ${ }^{17-19}$ These polymorphisms are of considerable practical importance because they may lead on the one hand to an overdose of local anaesthetics, but on the other hand to a successful treatment of otherwise fatal alkyl phosphate poisoning. ${ }^{20}$ The symptoms reported after carbamate and alkyl phosphate intoxication are similar, but in intoxication by carbamate, symptoms disappear much earlier and fatal developments are rare. By contrast with alkyl phosphates, after carbamate poisonings plasma and erythrocyte cholinesterase activities return to the initial level within a few hours. ${ }^{15}$

\section{Material and methods}

Data on 169 workers handling ethylparathion, 135 handling methylparathion, 233 handling propoxur, 440 handling cyfluthrin, 19 handling methyl-parathion and cyfluthrin, and seven handling propoxur and cyfluthrin are presented. The concentration of each pesticide in plasma and the corresponding metabolites in urine was measured. An overview of the applied methods is given in table 1 . The activities of the cholinesterases in plasma and the acetylcholinesterase in erythrocytes were assessed directly by kinetic enzyme/substrate measurements as already described. ${ }^{27}$ The creatinine content of the urine was measured as described previously. ${ }^{28}$ The analytical methods used were subject to statistical quality control 
Table 2 Mean findings of 127 workers after an ethylparathion accident

\begin{tabular}{lllllc}
\hline $\begin{array}{l}\text { Workers } \\
(n)\end{array}$ & $\begin{array}{l}\text { Ethylparathion } \\
(\mu g / l \text { plasma })\end{array}$ & $\begin{array}{l}\text { Ethylparaoxon } \\
(\mu g / l \text { plasma })\end{array}$ & $\begin{array}{l}\text { ChE } \\
\text { inhibition } \\
(\%)\end{array}$ & $\begin{array}{l}\text { AChE } \\
\text { inhibition } \\
(\%)\end{array}$ & $\begin{array}{l}\text { Symptom } \\
\text { frequency } \\
n(\%)\end{array}$ \\
\hline 24 & 650 & $<10$ & 12 & 9 & 0 \\
39 & 580 & $10-50$ & 84 & 47 & $4(10)$ \\
55 & 530 & $50-100$ & 100 & 71 & $31(56)$ \\
9 & 610 & $>100$ & 100 & 78 & $9(100)$ \\
\hline
\end{tabular}

Blood was drawn 30 minutes after exposure. $\mathrm{ChE}=$ cholinesterase activity; $\mathrm{AChE}=$ erythrocyte acetylcholinesterase activity.

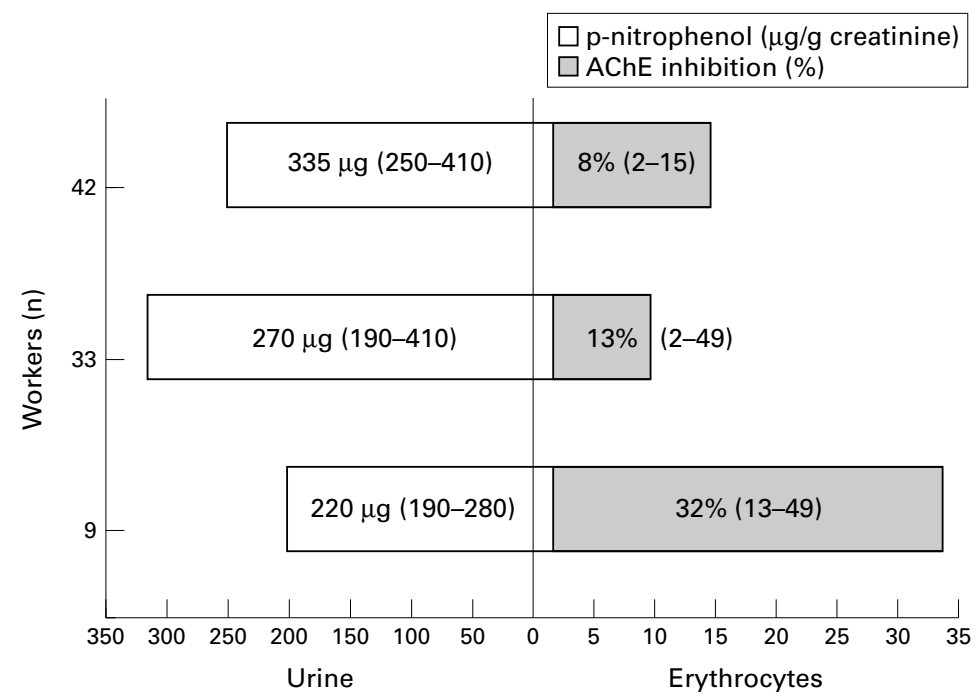

Findings of 42 workers routinely handling ethylparathion $\left(25 \mu \mathrm{g} / \mathrm{m}^{3}\right)$. Median (range) values are given. AChE=erythrocyte acetylcholinesterase activity.

in accordance with the German TRGS 410 (technical guidance for harmful substances). ${ }^{29-31}$ Parathion concentration in air was measured as already described. ${ }^{32}$

\section{Results}

PARATHION

Table 2 presents findings of 127 workers after accidents with ethylparathion (data given as averages). Blood was drawn 30 minutes after the accident. There was a relation between the concentration of ethylparaoxon in plasma and cholinesterase inhibition. This was not the case for ethylparathion. The workers mentioned had increased salivation, running nose, productive cough, visual disturbances, headache, and gastrointestinal irritations. There was a correlation between the frequency of symptoms reported and the plasma concentration of ethylparaoxon. Moreover, the extent of inhibition of cholinesterase and acetylcholinesterase correlated with the frequency of symptoms.

After acute ethylparathion intoxications, ethylparathion was detectable in plasma up to 16 hours later and the metabolite p-nitrophenol

Table 3 Mean findings of 135 workers with different individual baseline AChE activities after a propoxur accident

\begin{tabular}{llllc}
\hline Workers (n) & $\begin{array}{l}\text { AChE baseline } \\
\text { values (U/l) }\end{array}$ & $\begin{array}{l}\text { Propoxur } \\
\text { (ug/l plasma) }\end{array}$ & $\begin{array}{l}\text { AChE inhibition } \\
(\%)\end{array}$ & $\begin{array}{l}\text { Symptom } \\
\text { frequency } n(\%)\end{array}$ \\
\hline 4 & $>4000$ & 960 & 17 & 0 \\
31 & $3000-4000$ & 850 & 21 & 0 \\
45 & $2000-3000$ & 630 & 29 & $4(9)$ \\
38 & $1000-2000$ & 710 & 47 & $10(26)$ \\
17 & $<1000$ & 490 & 64 & $13(76)$ \\
\hline
\end{tabular}

Blood was drawn 30 minutes after the accident; for the determination of the individual baseline $\mathrm{AChE}$ values blood was drawn in the pre-employment medical examination. AChE=erythrocyte acetylcholinesterase activity; reference values for $\mathrm{AChE}=2900-4100 \mathrm{U} / \mathrm{.}^{27}$ was excreted in the urine for up to 4 weeks. Cholinesterase activity regenerated at a rate of $3 \%-9 \%$ a day and acetylcholinesterase activity at a rate of $1 \%-2 \%$ a day (data not shown). ${ }^{15}$

The figure shows data (median (range)) for 42 workers routinely handling ethylparathion. This group of workers was divided into two groups ( $n=33$ and $n=9$ ) depending on the correlation between high p-nitrophenol excretion and low inhibition of acetylcholinesterase and vice versa. Although, the level of exposure was the same for all workers $\left(25 \mu \mathrm{g} / \mathrm{m}^{3}\right.$ air), the concentration of p-nitrophenol in the urine varied between 190 and $410 \mu \mathrm{g} / \mathrm{g}$ creatinine and the acetylcholinesterase was inhibited between $2 \%$ and $49 \%$. Sampling was performed at the end of the workshift. The lower the p-nitrophenol concentration in the urine, the more the inhibition of acetylcholinesterase. Thus, from the relation between the inhibition of erythrocyte acetylcholinesterase and the extent of p-nitrophenol excretion, indirect information on the variation of paraoxonase activity could be obtained.

\section{PROPOXUR}

Twenty four workers exposed for 4 hours to propoxur $\left(2.0 \mathrm{mg} / \mathrm{m}^{3}\right)$ were investigated (no accident occurred). No measurable inhibition of acetylcholinesterase and cholinesterase was found. The metabolite of propoxur 2-isopropoxyphenol was mainly excreted during the first 8 hours. Twenty four hours after exposure 2-isopropoxyphenol was no longer detected in the urine (data not shown).

Table 3 shows data of 135 workers exposed to propoxur after an accident. Blood was drawn 30 minutes after the intoxication. After the intoxication, the inhibition of acetylcholinesterase varied between $17 \%$ and $64 \%$. The individual acetylcholinesterase activity was measured in the pre-employment medical examination. In 100 workers the preemployment acetylcholinesterase activity was below the range of the published reference values (2900-4100 U/1). ${ }^{27}$ The values of inhibition of acetylcholinesterase were related to the individual pre-exposure values. The absolute inhibition of acetylcholinesterase was similar in all the subjects and the different percentage was due to the different individual baseline. The symptoms lacrymation, sweating, tiredness, dizziness, and visual disturbances were only mentioned from workers whose baseline acetylcholinesterase activity was $<3000$ U/1. Symptoms were assessed by a medical doctor during the examination.

\section{CYFLUTHRIN}

In table 4 data of 10 workers exposed to cyfluthrin are presented. As a marker of exposure, cyfluthrin was measured in plasma. Cyfluthrin is rapidly metabolised as shown by the course. Assuming a simple first order decay of cyfluthrin in plasma, the individual half life differed widely between people (0.5-2 hours). Skin paraesthesia of the exposed area, burning, tingling, and itching sensations of the skin were reported twice. The other workers did not have any symptoms. Symptoms were assessed by a 
Table 4 Findings of 10 workers exposed to cyfluthrin

\begin{tabular}{|c|c|c|c|c|c|c|c|}
\hline Cases & Age (y) & $\begin{array}{l}\text { Type of } \\
\text { exposure }\end{array}$ & Exposure path & $\begin{array}{l}\text { Sampling time } \\
\text { after exposure }\end{array}$ & 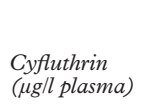 & $\begin{array}{l}\text { Cyfluthrin } \\
\text { half life in } \\
\text { plasma } \\
\text { (min) }\end{array}$ & $\begin{array}{l}\text { Symptom type } \\
\text { (duration) }\end{array}$ \\
\hline 1 & 24 & Intoxication & Oral/inhalative/dermal & $\begin{array}{l}35 \mathrm{~min} \\
3 \mathrm{~h}\end{array}$ & $\begin{array}{r}189 \\
34\end{array}$ & 59 & Skin paraesthesia $(5 \mathrm{~h})$ \\
\hline 2 & 45 & $"$ & $"$ & $\begin{array}{l}38 \mathrm{~min} \\
2 \mathrm{~h}\end{array}$ & $\begin{array}{l}93 \\
48\end{array}$ & 86 & Skin paraesthesia $(1 \mathrm{~h})$ \\
\hline 3 & 38 & $"$ & $"$ & $\begin{array}{l}28 \mathrm{~min} \\
2 \mathrm{~h}\end{array}$ & $\begin{array}{l}74 \\
19\end{array}$ & 47 & None \\
\hline 4 & 29 & $"$ & Oral/inhalative & $\begin{array}{l}30 \mathrm{~min} \\
2 \mathrm{~h}\end{array}$ & $\begin{array}{l}38 \\
11\end{array}$ & 50 & None \\
\hline 5 & 43 & $"$ & Oral/inhalative & $\begin{array}{l}25 \mathrm{~min} \\
1 \mathrm{~h}\end{array}$ & $\begin{array}{r}21 \\
6\end{array}$ & 19 & None \\
\hline 6 & 31 & $"$ & Dermal & $\begin{array}{l}50 \mathrm{~min} \\
2 \mathrm{~h}\end{array}$ & $\begin{array}{r}13 \\
3\end{array}$ & 33 & None \\
\hline 7 & 45 & $"$ & Dermal & $\begin{array}{l}30 \mathrm{~min} \\
1 \mathrm{~h}\end{array}$ & $\begin{array}{l}34 \\
12\end{array}$ & 20 & None \\
\hline $8^{\star}$ & 27 & Production & Oral/inhalative/dermal & $16 \mathrm{~h}$ & $<0.5$ & - & None \\
\hline $9^{\star}$ & $\begin{array}{l}33 \\
56\end{array}$ & Filling & $"$ & $16 \mathrm{~h}$ & $\begin{array}{r}2.7 \\
<05\end{array}$ & - & None \\
\hline
\end{tabular}

* Investigated at the annual occupational health preventive examination. Half life of cyfluthrin in plasma is assumed to follow a simple first order decay.

Table 5 Mean findings of workers handling methylparathion, propoxur and cyfluthrin

\begin{tabular}{|c|c|c|c|c|c|c|c|}
\hline \multirow[b]{2}{*}{ Exposures } & \multirow[b]{2}{*}{$\begin{array}{l}\text { Workers } \\
(n)\end{array}$} & \multirow[b]{2}{*}{$\begin{array}{l}\text { Methylparathion } \\
\text { (ug/l plasma) }\end{array}$} & \multirow[b]{2}{*}{$\begin{array}{l}\text { Propoxur } \\
\text { ( } \mu g / l \text { plasma) }\end{array}$} & \multicolumn{2}{|l|}{ Cyfluthrin } & \multirow{2}{*}{$\begin{array}{l}\text { AChE } \\
\text { inhibition } \\
(\%)\end{array}$} & \multirow{2}{*}{$\begin{array}{l}\text { Clinical } \\
\text { symptom } \\
\text { frequency } \\
n(\%)\end{array}$} \\
\hline & & & & $(\mu g / l \text { plasma })^{*}$ & $\begin{array}{l}\text { Half life in } \\
\text { plasma (min) }\end{array}$ & & \\
\hline \multirow[t]{5}{*}{ Single substances } & 135 & 233 & - & - & - & 49 & $0(0)$ \\
\hline & 74 & - & 784 & - & - & 53 & $8(11)$ \\
\hline & 427 & - & - & 96 & 39 & 9 & 0 \\
\hline & $3+$ & - & - & 89 & 137 & 9 & $3(0.7)$ \\
\hline & 12 & 269 & - & 139 & 54 & 47 & 0 \\
\hline \multirow[t]{2}{*}{ Mixtures } & $7 \dagger$ & 241 & - & 135 & 312 & 44 & 7 (37) \\
\hline & 7 & - & 837 & 145 & 76 & 51 & $0(0)$ \\
\hline
\end{tabular}

Blood was drawn at the end of the workshift except for cyfluthrin exposure ( $30 \mathrm{~min}$ and $3 \mathrm{~h}$ after exposure).

*Concentration of cyfluthrin 30 min after exposure.

†Individual data is shown in table 6. Half life of cyfluthrin in plasma is assumed to follow a simple first order decay. $\mathrm{AChE}=$ erythrocyte acetylcholinesterase activity.

medical doctor during the examination. In the first case the high initial cyfluthrin concentration may explain the symptom whereas in the second case the slow metabolic rate seems to be the predominant factor for the presence of the symptom.

Table 6 Individual data from table 5 for seven workers with mixed exposure to methylparathion and cyfluthrin compared with three workers with single exposure to cyfluthrin (all of these workers reported symptoms)

\begin{tabular}{|c|c|c|c|c|c|}
\hline Cases & $\begin{array}{l}\text { Sampling } \\
\text { times after } \\
\text { exposure }\end{array}$ & $\begin{array}{l}\text { Methylparathion } \\
\text { ( } \mathrm{g} / \text { l plasma) }\end{array}$ & $\begin{array}{l}\text { Cyfluthrin } \\
\text { ( } \mu g \text { /l plasma) }\end{array}$ & $\begin{array}{l}\text { Cyfluthrin } \\
\text { half life in } \\
\text { plasma ( } h \text { ) }\end{array}$ & $\begin{array}{l}\text { AChE } \\
\text { inhibition } \\
(\%)\end{array}$ \\
\hline \multirow[t]{2}{*}{1} & $30 \mathrm{~min}$ & 217 & 155 & & \\
\hline & $4 \mathrm{~h}$ & & 101 & 6 & 46 \\
\hline \multirow[t]{2}{*}{2} & $30 \mathrm{~min}$ & 257 & 138 & & \\
\hline & $4 \mathrm{~h}$ & & 99 & 7 & 51 \\
\hline \multirow[t]{2}{*}{3} & $30 \mathrm{~min}$ & 189 & 171 & & \\
\hline & $4 \mathrm{~h}$ & & 144 & 14 & 37 \\
\hline \multirow[t]{2}{*}{4} & $30 \mathrm{~min}$ & 314 & 98 & & \\
\hline & $3 \mathrm{~h}$ & & 40 & 2 & 53 \\
\hline \multirow[t]{2}{*}{5} & $30 \mathrm{~min}$ & 205 & 120 & & \\
\hline & $3 \mathrm{~h}$ & & 55 & 2 & 31 \\
\hline \multirow[t]{2}{*}{6} & $30 \mathrm{~min}$ & 234 & 116 & & \\
\hline & $3 \mathrm{~h}$ & & 58 & 3 & 58 \\
\hline \multirow[t]{2}{*}{7} & $30 \mathrm{~min}$ & 272 & 147 & & \\
\hline & $3 \mathrm{~h}$ & & 76 & 3 & 34 \\
\hline \multirow[t]{2}{*}{1} & $30 \mathrm{~min}$ & & 97 & & \\
\hline & $3 \mathrm{~h}$ & - & 30 & 1.5 & 9 \\
\hline \multirow[t]{2}{*}{2} & $30 \mathrm{~min}$ & & 95 & & \\
\hline & $3 \mathrm{~h}$ & - & 48 & 2.5 & 9 \\
\hline \multirow[t]{2}{*}{3} & $30 \mathrm{~min}$ & & 74 & & \\
\hline & $3 \mathrm{~h}$ & - & 40 & 2.8 & 12 \\
\hline
\end{tabular}

AChE=erythrocyte acetylcholinesterase activity.

Half life of cyfluthrin in plasma is assumed to follow a simple first order decay.
MIXED EXPOSURE

Table 5 shows the frequencies of reported symptoms after different exposure scenarios. Blood was drawn at the end of the workshift. Only for cyfluthrin, was blood drawn twice (30 minutes and 3 hours after exposure). After an exposure to methylparathion, no symptoms were reported. At an average propoxur concentration of $784 \mu \mathrm{g} / \mathrm{l}$ plasma, eight workers reported symptoms - such as tiredness, sweating, etc - and at an average cyfluthrin concentration of $96 \mu \mathrm{g} / 1$ plasma, three workers reported irritations of the eyes, mouth, throat, or skin. These three workers had a slow degradation rate in common (half life: $2.3 \mathrm{~h}$ ). Individual data for these three workers is shown in table 6. Mixed exposure to methylparathion and cyfluthrin caused skin paraesthesia in seven workers (individual data are shown in table 6), whereas there were no clinical abnormalities after simultaneous exposures to pyrethroid and carbamate. In these cases, cyfluthrin was degraded with a half life of about 1 hour.

\section{Discussion}

The aim of this study was to present some criteria for evaluating an individual exposure to pesticide. To meet this task, workers exposed (single or mixed exposure) to the pesticides methyl or ethylparathion (alkyl phosphates), 
propoxur (carbamate), or cyfluthrin (pyrethroid) were investigated.

To assess exposure to alkyl phosphate-for example, parathion-paraoxon and the main metabolite p-nitrophenol should be measured in plasma and urine after exposure. Simultaneous determination of p-nitrophenol and acetylcholinesterase activity provides indirect information on the activity of the individual paraoxonase. The pathophysiological effects of alkyl phosphates are independent of their chemical structures. It is thus sufficient to measure the inhibition of activity of acetylcholinesterase in each worker to be able to estimate the associated adverse health effects. This procedure is only appropriate if the specific effect of a pesticide on short term overexposure is identical to the effect of long term low dose exposure. It was shown in the scientific literature that after alkyl phosphate poisoning the measurement of acetylcholinesterase can be used as a representative biomarker for the effects of alkyl phosphates in the neurons and as a criterion for deciding whether to use an antidote. ${ }^{10}$

For assessing exposure to carbamate-for example, propoxur-propoxur in plasma and 2-isopropoxyphenol in urine can be measured. The individual acetylcholinesterase baseline activity plays an important part in the occurrence of symptoms after intoxication. Therefore, as a marker of susceptibility the erythrocyte acetylcholinesterase should be determined in workers before they handle carbamates or alkyl phosphates.

The pyrethroid cyfluthrin is metabolised very quickly with the elimination half life for the metabolites being about 6 hours. ${ }^{33}$ For assessing a pyrethroid exposure the corresponding metabolites are routinely measured in urine. ${ }^{1433-35}$ However, several studies have shown that there is no correlation between the metabolite concentration in urine and the symptoms mentioned. ${ }^{36}$ On the other hand, cyfluthrin can only be measured in plasma up to several hours after exposure. By contrast with alkyl phosphates and carbamates, pyrethroids do not inhibit the activity of cholinesterase..$^{25}$ It is not yet known which enzyme would be a suitable marker of pyrethroid susceptibility. ${ }^{1625}$ Workers with a high rate of metabolism reported symptoms less often than subjects with a low metabolic rate. This tendency was also evident for mixed exposure (cyfluthrin and parathion). Therefore, the individual rate of cyfluthrin degradation in plasma can be considered to be an indirect indicator of enzyme activity.

Sometimes an exposure to several pesticides has to be evaluated. With a common metabolic pathway synergistic effects might be possible. However, in this study only seven out of 19 workers exposed to pyrethroid and organophosphate reported symptoms. They all had a slow metabolism. Exposure to pyrethroid and carbamate did not lead to any complains.

\section{Conclusions}

In the assessment of exposure to pesticides, the importance of individual susceptibility has to be taken into account. At the same dose level, individual susceptibility determines whether or not a clinical intoxication or symptoms appear. For an occupational or environmental medical assessment in workers routinely handling pesticides it is desirable not only to measure the unchanged pesticides in the blood and their metabolites in the urine, but efforts should be made to investigate the individual metabolism - for example, by directly measuring the relevant enzymes or by determining the half life of the pesticide.

1 Abelson PH. Exaggerated risks of chemicals. $f$ Clin Epidemiol 1995;48:173-8

2 Lewalter J, Neumann H-G. Biologisches ArbeitsstoffToleranzwerte (Biomonitoring), Teil VIII: Bewertung der Hintergrundbelastungen bei beruflich nicht-exponierten
Personen. Arbeitsmed Sozialmed Umweltmed 1996;31:418-32.

3 Aitio A. Biological monitoring today and tomorrow. Scand $\mathcal{f}$ Work Environ Health 1994;20:46-58.

4 Hoet P, Haufroid V. Biological monitoring: state of the art. Occup Environ Med 1997;54:361-6.

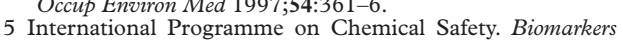
International Programme on Chemical Safety. Biomarkers and risk assessment: concept and principles. Geneva: World ria 155.)

6 Lewalter J. Monitoring und immunologische Bedeutung von Schadstoffaddukten. Berichte der Österreichischen Gesselschaft Klinische Chemie 1994;17:9-18.

7 Zielhuis RL, Henderson PTh. Definitions of monitoring activities and their relevance for the practice of occupational health. Int Arch Occup Environ Health 1986;57:249-57.

8 European Centre for Ecotoxicology and Toxicology of Chemicals. DNA and protein adducts: evaluation of their use in exposure monitoring and risk assessment. ECETOC, 1989. (Monograph No 13 .

9 Lewalter J. Biologisches Monitoring von Pestiziden. 5. Pflanzenschutz- und SchädlingsbekämpfungsmittelKolloquium [abstract]. Erlangen, Germany: Angerer J, 1996.

10 Lewalter J, Korallus U. Erythrocyte protein conjugates as a principle of biological monitoring for pesticides. Toxicol Lett 986;33:153-65.

11 Schulte PA. Review: a conceptual framework for the validation and use of biological markers. Environ Res 1989;48: $129-44$

12 Lewalter J, Neumann H-G. Biologische ArbeitsstoffToleranzwerte (Biomonitoring), Teil XII: Die Bedeutung der individuellen Empfindlichkeit beim Biomonitoring. Arbeitsmed Sozialmed Umweltmed 1998;33:352-64.

13 Roots J. Genetische Ursachen für die Variabilität der Wirkungen und Nebenwirkungen von Arzneimitteln. Der Internist 1982;23:601-9.

14 Wollen BH, Marsh JR, Laird WJD, et al. The metabolism of cypermethrin in man: differences in urinary metabolite profiles following oral and dermal administration. Xenobiotica 1992;22:983-91.

15 Lewalter J. Acetylcholinesterase inhibitors. In: Greim H, Lehnert G, eds. Biological exposure values for occupational toxicants and carcinogens. Weinheim, Germany: German toxicants and carcinogens. Weinheim, Germany: German Science

16 Aldridge WN. An assessment of the toxicological properties of pyrethroids and their neurotoxicity. Toxicology 1990;21: $89-104$.

17 Calabrese EJ. Ecogenetics: historical foundation and current status. F Occup Med 1986;28:1096-102.

18 Idle JR, Armstrong M, Boddy A, et al. The pharmacogenetics of chemical carcinogenesis. Pharmacogenetics 1992;2: 246-58.

19 Kalow W, Staron N. On the distribution and inheritance of atypical forms of human serum cholinesterase, as indicated by dibucaine numbers. Canadian fournal of Biochemistry 1957;35:1305-9.

20 Löhr GW. Über die Bedeutung genetisch bedingter Enzymdefekte für die Pharmakotherapie. In: Löhr GW, Blum KU, Wiedemann OJ, eds. Enzyme und Pharmaka. Grenzach: Wiedemann OJ, eds. Enzyme
Editiones Roche, 1970:79-101.

21 Lewalter J, Maniatis H. Parathion (-methyl), paraoxon (-methyl) in plasma. In: Angerer J, Schaller $\mathrm{KH}$, eds. Analyses of hazardous substances in biological materials. Weinheim, Germany: Deutsche Forschungsgemeinschaft, VCH Verlagsgesellschaft, 1999 (in press).

22 Lewalter J, Gries W, Kahre H, et al. o- und $p$-Nitrophenol in Harn, In: Angerer J, Schaller KH, eds. Analyses of hazardous substances in biological materials. Weinheim, Germany: Deutsche Forschungsgemeinschaft, VCH Verlagsgesellschaft, 1999 (in press)

23 Lewalter J, Wimber M. Propoxur in plasma. In: J Angerer, KH Schaller, eds. Analyses of hazardous substances in biological materials. Weinheim, Germany: Deutsche Forschungsgemeinschaft, VCH Verlagsgesellschaft. 1999 (in press).

24 Lewalter J, Schucht Th, Angerer J, et al. Benzene derivatives, suitable for steam distillation. In: Angerer J, Schaller KH, eds. Analyses of hazardous substances in biological materials. Weinheim, Germany: Deutsche Forschungsgemeinschaft, Geinheim, Germany: Deutsche Forschungsgemeinschaft, 1985;1:31-56. 
25 Leng G, Kühn K-H, Idel H. Biological monitoring of pyrethroids in blood and pyrethroid metabolites in urine: applications and limitations. Sci Total Environ 1997;199: 173-81

26 Lewalter J, Kahre H. Cyfluthrin in plasma. In: Angerer J, Schaller KH, eds. Analyses of hazardous substances in biological materials. Weinheim, Germany: Deutsche Forschungsgemeinschaft, VCH Verlagsgesellschaft, 1999 (in press).

27 Lewalter J, Domik C, Schaller KH. Acetylcholinesterase and cholinesterase in plasma and erythrozyten. In: Angerer J, Schaller KH, eds. Analyses of hazardous substances in biological materials. Weinheim, Germany: German Science Foundation, VCH Verlagsgesellschaft, 1991;3:45-61.

28 Siedel J, Möllering H, Ziegenhorn J. Sensitive color reagent for the enzymic determination of creatinine. Clin Chem 1984;30:968-9.

29 Schaller KH, Angerer J, Lehnert G. Current status of the external quality assurance programmes of the German Society for Occupational and Environmental Medicine. Toxicol Lett 1995;77:213-7.

30 Schaller KH, Angerer J, Lehnert G. Biologische Arbeitsstoff-Toleranzwerte (Biomonitoring), Teil VII: Arbeitsstoff-Toleranzwerte (Biomonitoring), Teil VII:
Qualitätssicherung arbeitsmedizinisch-toxikologischer Analysen - Erfordernisse für die ärztliche Beurteilung von
Ergebnissen des Biomonitoring. Arbeitsmed Sozialmed Umweltmed 1996;31:317-23.

31 Technische Regel für gefährliche Arbeitsstoffe 410 (TRgA 410). Statistische Qualitätssicherung. Bundesarbeitsblatt. 1979;6:88-92

32 Riegner K. Modifikation der Methode 00323 (RA-251/93) zur Bestimmung von Parathion-ethyl in Luft. BAYER AG, unveröffentlichter Bericht, RA-174/94, Methode 00323-M001, 1994. Leverkusen, Germany: Bayer, 1994.

33 Leng G, Leng A, Kühn K-H, et al. Human dose-excretion studies with the pyrethroid insecticide cyfluthrin: urinary metabolite profile following inhalation. Xenobiotica 1997; 27:1272-83

34 Kühn K-H, Leng G, Bucholski K A, et al. Determination of pyrethroid metabolites in human urine by capillary gas chromatography-mass spectrometry. Chromatographia 1996;43:285-92.

35 Leng G, Kühn K-H, Kühn I H. Biological monitoring of pyrethroid metabolites in urine of pest control operators. pyrethroid metabolites in urine

36 Kolmodin-Hedman B, Akerblom M, Flato S, et al. Symptoms in forestry workers handling conifer plants treated with permethrin. Bull Environ Contam Toxicol 1995; 55:487-93.

\section{Rejected manuscripts}

From February 1994, authors whose submitted articles are rejected will be advised of the decision and one copy of the article, together with any reviewer's comments, will be returned to them. The fournal will destroy remaining copies of the article but correspondence and reviewers' comments will be kept. 